\title{
In Vitro Investigation of the Antibacterial Effect of Silver Nanoparticles on ESBL-producing $E$. coli and Klebsiella spp. Isolated from Pet Animals
}

\author{
Omnia A Khalil ${ }^{1}$, Mona I Enbaawy ${ }^{1}$, Taher Salah ${ }^{2}$, Hossam Mahmoud ${ }^{1}$ and Eman Ragab ${ }^{1 *}$ \\ ${ }^{l}$ Microbiology Department, Faculty of Veterinary Medicine, Cairo University, Egypt \\ ${ }^{2}$ Agricultural Research Center (ARC), Biological fluid Department, Giza, Egypt \\ *Corresponding author`s Email: eman_ragab2008@cu.edu.eg; (DORCiD: 0000-0001-7363-2496
}

\begin{abstract}
Despite the presence of modern antibacterial drugs, bacterial infections are still a major threatening problem due to the enormous increase in multi-drug-resistant bacteria. Nanoparticles have been extensively used as an applicable and safe alternative to antibiotics. The present study aimed to explore the inhibitory effect of silver nanoparticles on Extended Spectrum Beta lactamase (ESBL) producing E. coli and Klebsiella spp. in vitro as well as their effect on the expression of antibiotic resistance genes. Different samples (i.e., wound swabs, Fecal swabs, and urine samples) were collected from dogs and cats. Phenotypic and molecular identification, antibiotic susceptibility testing, and double-disk synergy test were carried out for the identification of ESBL producing E. coli and Klebsiella spp. Silver nanoparticles were tested for their in vitro antibacterial potential and there were reports of their minimum inhibitory concentration and minimum bactericidal concentration. Moreover, the effect of silver nanoparticles on the expression of antibiotic resistance genes (i.e., blaTEM, blaSHV, and blaCTX) was assessed as well as their effect on the structural integrity of the bacterial cells using Scanning Electron Microscope (SEM). Results revealed that 23 isolates $(19.16 \%)($ E. coli=17, Klebsiella $\mathrm{spp} .=6)$ were confirmed as ESBL producing. Silver nanoparticles indicated a promising antibacterial effect where the minimum inhibitory concentration of AgNPs for ESBL producing E. coli was measured as $0.31 \mathrm{mg} / \mathrm{ml}$, and $0.62 \mathrm{mg} / \mathrm{ml}$ for ESBL-producing Klebsiella spp., while the minimum bactericidal concentration of ESBL-producing E. coli and Klebsiella spp. was reported as $0.15 \mathrm{mg} / \mathrm{ml}$ and $0.3 \mathrm{mg} / \mathrm{ml}$, respectively. Consequently, the expression of antibiotic resistance genes was downregulated in both bacteria species and there was a noticeable toxic effect of AgNPs on E. coli and Klebsiella spp. cells which was investigated using SEM. It can be concluded that silver nanoparticles have a promising antibacterial activity and could be considered an applicable alternative for the control of ESBL producing bacteria.
\end{abstract}

Keywords: E. coli, ESBLs, Klebsiella spp., Pets, Silver nanoparticles

\section{INTRODUCTION}

In the current decade, the search for antibiotic alternatives has become one of the most quintessential issues due to the massive expansion of antibiotic resistance. The usage of silver nanoparticles has been widely recognized due to their known bactericidal as well as bacteriostatic actions against different types of bacterial and fungal pathogens (Saeb et al., 2014). Silver nanoparticles (AgNPs) have a broad-spectrum antimicrobial effect due to their large surface area providing the chance for better contact with microbes ( $\mathrm{Li}$ et al., 2010). Furthermore, silver nanoparticles have a lower propensity to induce microbial resistance than other antimicrobial agents (Ansari et al., 2014). It is also worth mentioning that these nanoparticles have a non-toxic effect on the human at low concentrations (Bindu et al., 2015). They are characterized by their powerful antioxidant and antibacterial effect because of bioactive molecules on the exterior surface of silver nanoparticles (Keshari, 2020).

Extended Spectrum $\beta$-Lactamase producing bacteria (ESBL) are types of bacteria that show resistance to several types of antibiotics through the hydrolysis of the b-lactam ring of antibiotics (Kizilca et al., 2012) and they can transfer resistance to penicillins, third-generation cephalosporins, and monobactams (Ejaz et al., 2011). Moreover, most of them are not inhibited by other non-b-lactam antibiotics since the resistance encoding genes of other antibiotic classes can also be carried by the plasmids containing the ESBL-encoding genes (Alyamani et al., 2017; Fan et al., 2014). Escherichia coli and Klebsiella spp. remain the major ESBL-producing microorganisms isolated worldwide. They are considered the most emerging Extended-spectrum $\beta$-lactamase (ESBL) with a serious effect on the community (Devrim et al., 2011). The CTX-M-type enzymes are the largest ESBL groups spreading globally, followed by TEM and SHV groups (Sukmawinata et al, 2020). Researchers from different countries have successfully isolated and identified ESBLproducing bacteria from different types of samples, including isolates from human in Bahrain (Shahid et al., 2014), different samples (e.g., fecal swabs, animal feeds, water, and excreta ) from different animals ( e.g, dogs, cats, sheep, 
goat, chickens, turkey, ducks, and human, (Okapara et al., 2018), isolates of urine samples from dogs and cats in USA and Switzerland (Thungrat et al., 2015; Zogg et al., 2018), also isolates of fecal swabs from dogs and cats in Newzeland (Karkaba et al., 2019). Nanoparticles are known mainly by their direct action on the bacterial cell wall which is different from other antibiotic resistance mechanisms and needs no penetration of bacterial cells (Wang et al., 2019). Subsequently, they are less predisposed to develop resistance, compare to antibiotics. AgNps have proved a good antibacterial and antioxidant activity against E. coli and Klebsiella pneumoniae isolates (Khan et al., 2020). Moreover, it was demonstrated that AgNPs have a powerful toxic action on ampicillin resistant Klebsiella Pneumoniae genes and bacterial proteins as well as bacterial membrane damage and oxidative stress (Hamida et al., 2020). Therefore, this study aimed to explore the inhibitory effect of silver nanoparticles on ESBL-producing E. coli and Klebsiella spp. in vitro as well as their effect on the expression of resistance genes. In doing so, the phenotypic and molecular identification of ESBL producing E. coli and Klebsiella spp. was carried on different samples collected from dogs and cats living in various places in Egypt. The bactericidal activity of Ag nanoparticles was assessed via different microbiological and molecular techniques.

\section{MATERIALS AND METHODS}

\section{Ethical approval}

The study was conducted according to ethical guidelines approved by the Faculty of Veterinary Medicine, Cairo University. There were no experiments applied to human participants.

\section{Samples collection and preparation}

A total of 120 samples were collected from diseased dogs $(n=55)$ and cats $(n=65)$. All samples were collected according to the guidelines of the Institutional Animal Care and Use Committee at Cairo University and approved by Vet-CU-IACUC (Vet CU 16072020198), Cairo, Egypt. Written consent was obtained from the animal owners after they were informed on the use of their animal samples in the study. Samples included fecal swabs ( $n=61$ ), wound swabs $(n=17)$, and urine samples $(n=42)$. Samples were collected from Al-Shaab Veterinary Hospital, Surgery and Medicine Departments at Faculty of Veterinary medicine, Cairo University as well as animal laboratories in Cairo and Giza from March to December 2019. Samples were collected from animals suffering from gastrointestinal tract disturbances, and acute or chronic cystitis. In addition, the wounded animals had certain medical conditions and could provide no appropriate response to the prescribed antibiotics (Huber et al.,2013). All investigated samples were collected under aseptic conditions and safety precautions. Samples were directly inoculated into $9 \mathrm{ml}$ of sterile physiological saline (Okapara et al., 2018). Urine samples were collected from each case via catheter and urine was collected from the distal part under aseptic conditions by the collection of the midstream urine sample (Cystocentesis) as reported by Huber et al. (2013). Samples were appropriately labelled and transported without delay to the laboratory and processed immediately.

\section{Phenotypic characterization and Antibiogram testing for $\boldsymbol{E}$. coli and Klebsiella spp. isolates}

Wound and fecal swabs were inoculated onto MacConkey agar (Oxoid) supplemented with ampicillin (100 mg/L; Mac-AMP100, Oxoid) according to Okapara et al. (2018). Urine samples were centrifuged, and the sediment was inoculated directly on MacConkey agar (Oxoid). All inoculated plates were incubated at $37^{\circ} \mathrm{c}$ for $18-24$ hours and examined for bacterial growth. Both lactose fermenter colonies and late lactose fermenter colonies were selected for further examinations. The purified isolates were finally confirmed biochemically with citrate, oxidase, indole, catalase, Voges Proskauer, methyl red, urease, and triple sugar iron (TSI) tests according to Cruickshank et al. (1975). All isolates were tested for their susceptibility to different antimicrobial drugs and antibiotics (Table 1). The antimicrobial susceptibility test was performed using the disc diffusion method (Kibry-Bauer method) on Muller-Hinton agar plates (Oxoid) and the interpretation was performed based on CLSI (2018).

\section{Doubled-disc synergy test}

ESBL production was identified using Double Disk Synergy Test (DDST) according to Iqbal et al. (2017). Three

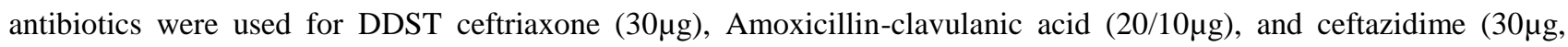
Oxoid). Discs were placed at a distance of $1.5 \mathrm{~cm}$. ESBL positive organism are showing development of the inhibition zone towards the clavulanate disc at $37^{\circ} \mathrm{C}$ after 24 -hours-incubation.

\section{Molecular characterization of ESBL-genes in E. coli and Klebsiella spp. isolates}

Extraction of DNA was performed using QIAmp DNA Mini Kit instructions (QIAGEN, Germany). Specific primers were used for the amplification of blaTEM, blaSHV, and blaCTX genes (Table 2). The preparation of the PCR Master Mix was performed according to Emerald Amp GT PCR Master Mix (Takara). The reaction mixture consisted of 12.5 $\mu l$ Emerald Amp GT PCR Master Mix (2x premix), $4.5 \mu l$ PCR grade water, $1 \mu l$ of each primer in the concentration 
of (20 pmol), $6 \mu \mathrm{l}$ of Template DNA, and leading to a total of $25 \mu l$. The cycling condition was like that used in (Hasman et al., 2005). The ladder was mixed gently by pipetting up and down, and $6 \mu$ of the required ladder was directly loaded. The PCR products were resolved by electrophoresis on an agarose gel according to Sambrook et al. (1989) with some modification.

Table 1. Antibiotics used in antimicrobial susceptibility test and their resistance pattern against E. coli and Klebsiella spp. isolates

\begin{tabular}{|c|c|c|c|c|c|c|c|}
\hline \multirow[b]{2}{*}{ Antibiotic } & \multirow{2}{*}{$\begin{array}{c}\text { Disc } \\
\text { content }\end{array}$} & \multicolumn{3}{|c|}{$\begin{array}{c}\text { Resistance } \\
\text { pattern of } E . \text { Coli }\end{array}$} & \multicolumn{3}{|c|}{ Resistance pattern of Klebsiella spp. } \\
\hline & & $\begin{array}{c}\text { Sensitive } \\
(\%)\end{array}$ & $\begin{array}{c}\text { Intermediate } \\
(\%)\end{array}$ & $\begin{array}{c}\text { Resistant } \\
(\%)\end{array}$ & $\begin{array}{c}\text { Sensitive } \\
(\%)\end{array}$ & $\begin{array}{c}\text { Intermediate } \\
(\%)\end{array}$ & $\begin{array}{c}\text { Resistant } \\
(\%)\end{array}$ \\
\hline \multicolumn{8}{|l|}{ Aminoglycosides } \\
\hline Amikacin & $30 \mu \mathrm{g}$ & 89 & 5 & 6 & 86 & 6 & 8 \\
\hline Gentamycin & $10 \mu \mathrm{g}$ & 53 & 18 & 29 & 72 & 0 & 28 \\
\hline Streptomycin & $10 \mu \mathrm{g}$ & 47 & 0 & 53 & 28 & 20 & 52 \\
\hline Kanamycin & $10 \mu \mathrm{g}$ & 31 & 13 & 56 & 60 & 12 & 28 \\
\hline \multicolumn{8}{|l|}{$\begin{array}{l}\text { Cephalosporins } \\
\left(1^{\text {st }} \text { generation }\right)\end{array}$} \\
\hline Cephalexin & $30 \mu \mathrm{g}$ & 8 & 0 & 92 & 18 & 6 & 76 \\
\hline \multicolumn{8}{|l|}{$\begin{array}{l}\text { Cephalosporins } \\
\left(3^{\text {rd }} \text { generation }\right)\end{array}$} \\
\hline Cefotaxime & $30 \mu \mathrm{g}$ & 9 & 4 & 87 & 52 & 0 & 48 \\
\hline Ceftazidime & $30 \mu \mathrm{g}$ & 19 & 0 & 81 & 36 & 4 & 60 \\
\hline Ceftriaxone & $30 \mu \mathrm{g}$ & 23 & 6 & 71 & 38 & 22 & 40 \\
\hline \multicolumn{8}{|c|}{ Miscellaneous antibiotics } \\
\hline Chloramphenicol & $10 \mu \mathrm{g}$ & 49 & 27 & 34 & 45 & 31 & 24 \\
\hline situoruminations & $300 \mu \mathrm{g}$ & 69 & 13 & 18 & 58 & 24 & 28 \\
\hline \multicolumn{8}{|l|}{ Other $\beta$ lactam } \\
\hline Aztreonam & $30 \mu \mathrm{g}$ & 41 & 6 & 53 & 66 & 10 & 24 \\
\hline \multicolumn{8}{|l|}{ Penicillins } \\
\hline Ampicillin & $10 \mu \mathrm{g}$ & 0 & 0 & 100 & 0 & 0 & 100 \\
\hline $\begin{array}{l}\text { Amoxycinln } \\
\text { Clavulanic acid }\end{array}$ & $(20 / 10) \mu \mathrm{g}$ & 37 & 0 & 63 & 32 & 8 & 60 \\
\hline \multicolumn{8}{|l|}{ Quinolones } \\
\hline Ciprofloxacin & $5 \mu \mathrm{g}$ & 71 & 11 & 18 & 88 & 0 & 12 \\
\hline Nalidixic acid & $30 \mu \mathrm{g}$ & 68 & 3 & 29 & 92 & 0 & 8 \\
\hline \multicolumn{8}{|l|}{ Tetracyclines } \\
\hline Tetracycline & $30 \mu \mathrm{g}$ & 34 & 6 & 60 & 42 & 22 & 36 \\
\hline
\end{tabular}

Table 2. Oligonucleotide primers and probes used in PCR and SYBR Green real-time PCR

\begin{tabular}{|c|c|c|c|}
\hline Gene & Primer sequence (5'-3') & $\begin{array}{c}\text { Amplification } \\
\text { size }\end{array}$ & Reference \\
\hline \multirow{2}{*}{$b^{b l a} a_{T E M}$} & ATCAGCAATAAACCAGC & \multirow[b]{2}{*}{$516 \mathrm{bp}$} & \multirow{4}{*}{ Colom et al. (2003) } \\
\hline & CCCCGAAGAACGTTTTC & & \\
\hline \multirow{2}{*}{$b l a_{S H V}$} & AGGATTGACTGCCTTTTTG & \multirow[b]{2}{*}{$392 \mathrm{bp}$} & \\
\hline & ATTTGCTGATTTCGCTCG & & \\
\hline \multirow{2}{*}{ blaCTX } & ATG TGC AGY ACC AGT AAR GTK ATG GC & \multirow[b]{2}{*}{$593 \mathrm{bp}$} & \multirow{2}{*}{$\begin{array}{l}\text { Archambault et } \\
\text { al. (2006) }\end{array}$} \\
\hline & TGG GTR AAR TAR GTS ACC AGA AYC AGC GG & & \\
\hline \multirow{2}{*}{ gyrA (Klebsiella spp.) } & CGC GTA CTA TAC GCC ATG AAC GTA & & \multirow{2}{*}{$\begin{array}{l}\text { Brisse and Verhoef } \\
\text { (2001) }\end{array}$} \\
\hline & ACC GTT GAT CAC TTC GGT CAG G & & \\
\hline \multirow{2}{*}{$\begin{array}{l}16 S \text { rRNA } \\
\text { (E. coli) }\end{array}$} & GCTGACGAGTGGCGGACGGG & \multirow[b]{2}{*}{-} & \multirow{2}{*}{$\begin{array}{l}\text { Tivendale et al. } \\
\text { (2004) }\end{array}$} \\
\hline & TAGGAGTCTGGACCGTGTCT & & \\
\hline
\end{tabular}

\section{In vitro assessment of the antibacterial effect of Ag NPs suspension}

Silver nanoparticles powder was purchased from the National Research Center, Egypt. The dispersion process was done using an ultrasonic processor (Cole-Parmer instruments, Illinois U.S.A.). For nanofluid preparation, $10 \mathrm{mg}$ of $\mathrm{Ag}$ NPs of average size $58 \mathrm{~nm}$ were dispersed in $1 \mathrm{ml}$ of sterile Muller Hinton broth and sonicated for 5 minutes at $20000 \mathrm{HZ}$ frequency from 3 to 5 times to avoid aggregation (Tayel et al., 2010). Pure colonies from both E. coli and Klebsiella spp. 
isolates were picked up and suspended in Muller Hinton broth. Suspensions were adjusted to match McFarland standard $0.5\left(1.5 \times 10^{8} \mathrm{CFU} / \mathrm{ml}\right)$ to be ready for antimicrobial testing. The tests were adapted according to CLSI (2018). The minimum inhibitory concentration (MIC) of AgNPs was determined in a sterile 96-well microtiter plate. The $100 \mu \mathrm{L}$ of sterile muller Hinton broth was pipetted into the well No.1 through No.12 of the column. In the next step, $100 \mu \mathrm{L}$ of the Ag NPs suspension (10mg/ml) were added into well No.1 of column (A), to reach a total volume of $200 \mu \mathrm{L}$ with a concentration of $(5 \mathrm{mg} / \mathrm{ml})$. Two-fold serial dilution was applied starting with the previously mentioned concentration. Later, $100 \mu \mathrm{L}$ of the E. coli suspension (McFarland 0.5) was added to the wells of the column, and then the initial concentration changed to $2.5 \mathrm{mg} / \mathrm{ml}$. Well No.11 served as a negative growth (sterility control) containing Ag NPs suspension plus sterile broth only while well No.12 was served as a positive bacterial control containing broth plus the bacterial inoculum only. These steps were repeated with Klebsiella spp. in another microtiter plate. The microtiter plates were incubated at $37{ }^{\circ} \mathrm{C}$ for 24 hours in a shaker incubator. The lowest concentration of Ag NPs in the series inhibiting the growth of the bacteria in vitro was taken as the MIC. For MBC determination, $50 \mu \mathrm{L}$ from each well was spread on MacConkey agar plates and incubated at $37^{\circ} \mathrm{C}$ for a further 48 hours. Growth-free plates validated that the used concentration inhibited bacterial growth. These tests were performed in triplicate.

\section{Assessment of the inhibitory effect of AgNPs on the expression of resistance genes in E. coli and Klebsiella spp. using SYBR Green RT- PCR}

The effect of sub-MIC dose (1/2) of AgNPs on the expression of blaTEM, blaSHV, and blaCTX genes was studied in the presence of 16s rRNA for E. coli and gyrA for Klebsiella spp. as housekeeping genes (Brisse and Verhoef, 2001; Tivendal et al., 2004). The RT-PCR procedure was performed in Reference Laboratory for Veterinary Quality Control on Poultry Production, Animal Health Research Institute, Egypt. Extraction of RNA was performed according to RNeasy Mini Kit instructions (QIAGEN, Germany, GmbH). Oligonucleotide primers and probes used in SYBR Green real-time PCR are shown in Table 2. PCR Master Mix QuantiTect SYBR Green PCR Kit was used. The reaction mixture consisted of $12.5 \mu l$ 2x QuantiTect SYBR Green PCR Master Mix, 0.25 $\mu$ l Revert Aid Reverse Transcriptase (ThermoFisher, $200 \mathrm{U} / \mu \mathrm{L}$ ), $0.5 \mu l$ of each primer (20 pmol), $8.25 \mu l$ RNase Free Water, $3 \mu l$ Template RNA, leading to a total of $25 \mu \mathrm{l}$. The cycling conditions were performed according to previous studies (Brisse and Verhoef, 2001; Colom et al., 2003; Tivendale et al., 2004; Archambault et al., 2006). Amplification curves and CT values were determined by the strata gene MX3005P software. To estimate the variation of gene expression of the different samples, the CT of each sample was compared with that of the control group according to the " $\Delta \Delta \mathrm{Ct}$ method CT" stated by Yuan et al. (2006) and samples were tested in triplicates. The dissociation curves of different samples were compared to exclude falsepositive results.

\section{Evaluation of morphological changes in E. coli and Klebsiella spp. upon their interaction with silver nanoparticles}

Samples included untreated samples (control) and AgNPs treated E. coli and Klebsiella spp. colonies. The samples were fixed by glutaraldehyde $2.5 \%$ and dehydrated by the serial dilution of ethanol with agitation using an automatic tissue processor (Leica EM TP, Leica Microsystems: Austria). In the next step, they were dried using $\mathrm{CO}_{2}$ critical point drier (Model: Audosamdri-815, Tousimis; Rockville, Maryland, USA). The samples were coated by a gold sputter coater (SPI-Module, USA). They were examined by Scanning electron microscopy (Model: JSM- 5500 LV; JEOL Ltd -Japan) using a high vacuum mode at the Regional Center of Mycology and Biotechnology, Cairo, Egypt.

\section{Statistical analysis}

Statistical analysis was performed using R-programme. One-way ANOVA was run to evaluate the statistical significance between the control and treated samples. P-value less than 0.05 was considered statistically significant.

\section{RESULTS}

\section{Phenotypic identification of $\boldsymbol{E}$. coli and Klebsiella spp. isolates}

Out of 120 samples, E. coli and Klebsiella spp. were detected in 62 (51.6\%) and 25 (20.8\%) cases, respectively. On MacConkey agar, E. coli appeared as medium-sized, smooth, round, lactose-fermenting colonies, pink to red with bile salt precipitate surrounding the colonies. On the other hand, Klebsiella spp. was observed as medium-sized, pink, lactose- fermenting, round, shiny, and mucoid colonies. Microscopic examination of Gram-stained pure colonies of $E$. coli and klebsiella spp. isolates were gram-negative rod-shaped bacteria. Isolates were confirmed biochemically. E. coli was negative in urease, oxidase, Voges Proskauer (vp), citrate tests while positive for catalase, methyl red (MR), Indole tests and A/A with gas production and negative $\mathrm{H}_{2} \mathrm{~S}$ production for TSI test. Klebsiella spp. was positive in urease, oxidase, Voges Proskauer, catalase and citrate test and A/A with gas production and negative indole, Methyl red, and $\mathrm{H}_{2} \mathrm{~S}$ production for TSI test. 


\section{Antimicrobial susceptibility testing}

Using different groups of antibiotics (Table 1), the antibiogram was assessed for E. coli and Klebsiella spp. isolates. Ampicillin showed the highest percentage for resistance in both E. coli and Klebsiella spp. as shown in the resistance pattern (Figure 1). The most prominent groups in resistance pattern were Cephalosporins first and third generation represented by Cephalexin (92\%, 76\%), Cefotaxime (87\%, 48\%), Ceftazidime (81\%, 60\%), Ceftriaxone (71\%, 40\%) for E. coli and Klebsiella spp., respectively. Moreover, Amoxicillin Clavulanic acid indicated $63 \%$ resistance for $E$. coli isolates and $60 \%$ for Klebsiella spp. The overall result of the antibiogram revealed that about 29 isolates $($. coli $=20$, Klebsiella $\mathrm{spp} .=9)$ were suspected to be ESBL producing isolates.

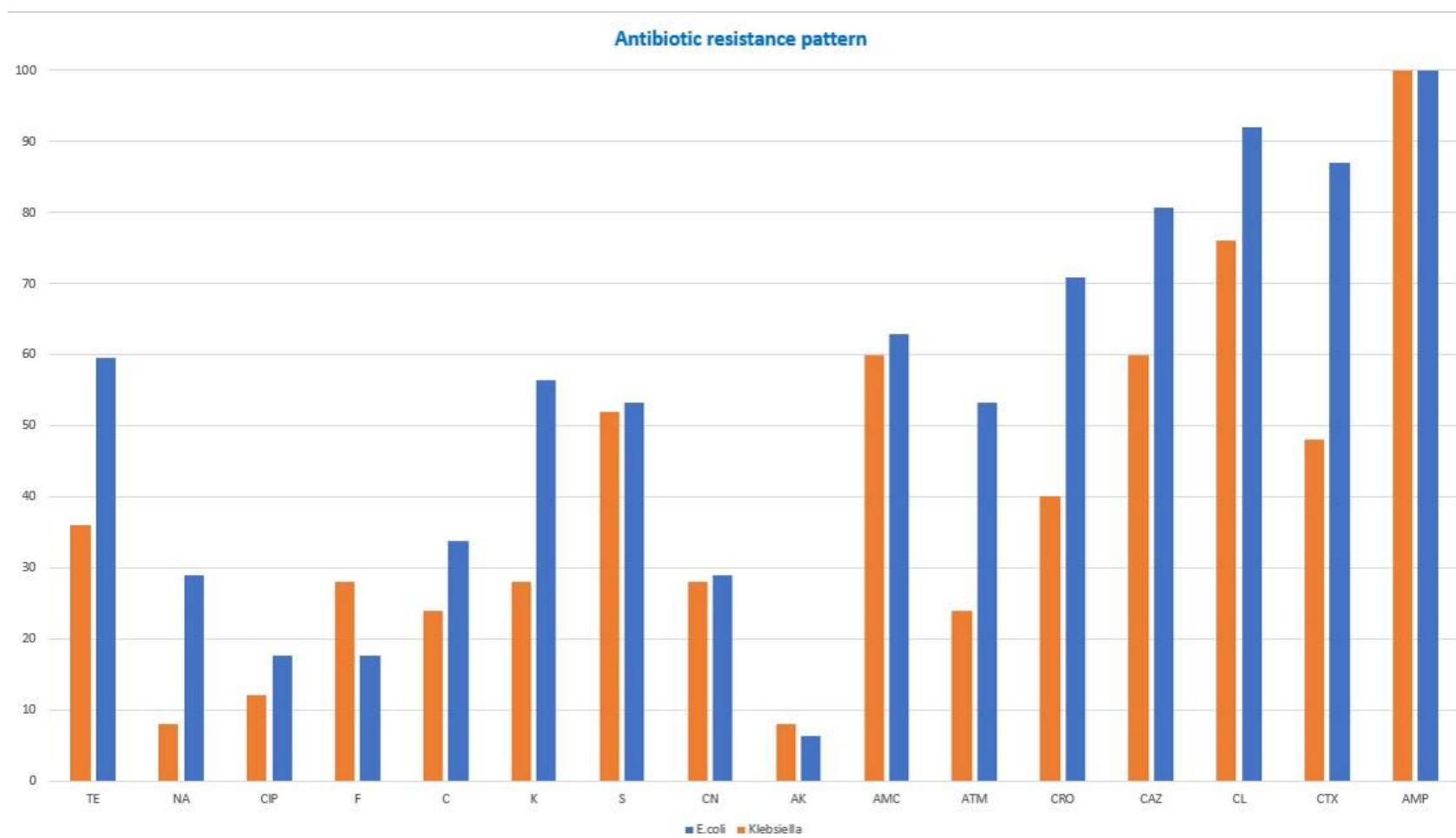

Figure 1. Antibiotic resistance pattern of the used antibiotics against E. coli and Klebsiella spp. isolates

\section{Double-disc synergy test method}

Detection of suspected isolates by DDST revealed that 23 isolates (E. coli=17, Klebsiella=6) were ESBL producing isolates. The number of isolated ESBL producing E. coli and Klebsiella spp. for each type of sample is demonstrated in Table 3 .

\section{Molecular detection of ESBL -encoding genes}

PCR screening of genes encoding ESBL revealed the presence of blaCTX, blaSHV, and blaTEM genes in all the tested isolates except one Klebsiella spp. isolate which did not harbor blaCTX gene (Figure 2).

\section{In vitro evaluation of the antibacterial effect of Ag NPs}

Scanning Electron Microscopy of AgNPs (Figure 3) revealed that Ag NPs were spherical with the average size of the $58 \mathrm{~nm}$. The MIC of AgNPs tested for ESBL-producing E. coli was $0.31 \mathrm{mg} / \mathrm{ml}$, and $0.62 \mathrm{mg} / \mathrm{ml}$ for ESBL-producing Klebsiella spp. The minimum bactericidal concentration (MBC) of ESBL-producing E. coli and Klebsiella spp. was 0.15 $\mathrm{mg} / \mathrm{ml}$ and $0.3 \mathrm{mg} / \mathrm{ml}$, respectively.

\section{Effect of sub MIC concentration of AgNPs on the expression of resistance genes.}

Expression of blaTEM, blaSHV, and blaCTX genes was downregulated with sub-MIC doses of AgNPs $(150 \mu \mathrm{g} / \mathrm{ml}$ for E. coli and $310 \mu \mathrm{g} / \mathrm{ml}$ for Klebsiella spp.), compared to untreated sample as shown in (Figure 4).

\section{Effect of silver nanoparticles on the integrity of cells}

The SEM images of untreated (control) cells showed healthy cells with clear unpenetrated cell membranes while treated cells showed cell membrane damage due to the adherence of AgNPs with the bacterial cell membrane and penetration into the cells causing cell death (Figure 5). 
Table 3. Prevalence of ESBL producers from dogs and cats in Egypt

\begin{tabular}{lccc}
\hline \multirow{2}{*}{ Origin } & \multicolumn{3}{c}{ No. of samples with ESBL producer (\%) } \\
\cline { 2 - 4 } & EC & KS & Total \\
\hline Wound swabs $(\mathrm{n}=17)$ & - & $2(11.7)$ & $2(11.7 \%)$ \\
Fecal swabs $(\mathrm{n}=61)$ & $10(16.4 \%)$ & $1(1.6 \%)$ & $11(18 \%)$ \\
Urine samples $(\mathrm{n}=42)$ & $7(16.7 \%)$ & $3(7.1 \%)$ & $10(23.8 \%)$ \\
Total $(\mathrm{n}=120)$ & $17(14.16 \%)$ & $6(5 \%)$ & $23(19.6 \%)$ \\
\hline
\end{tabular}

EC: Escherichia coli; KS: Klebsiella spp.
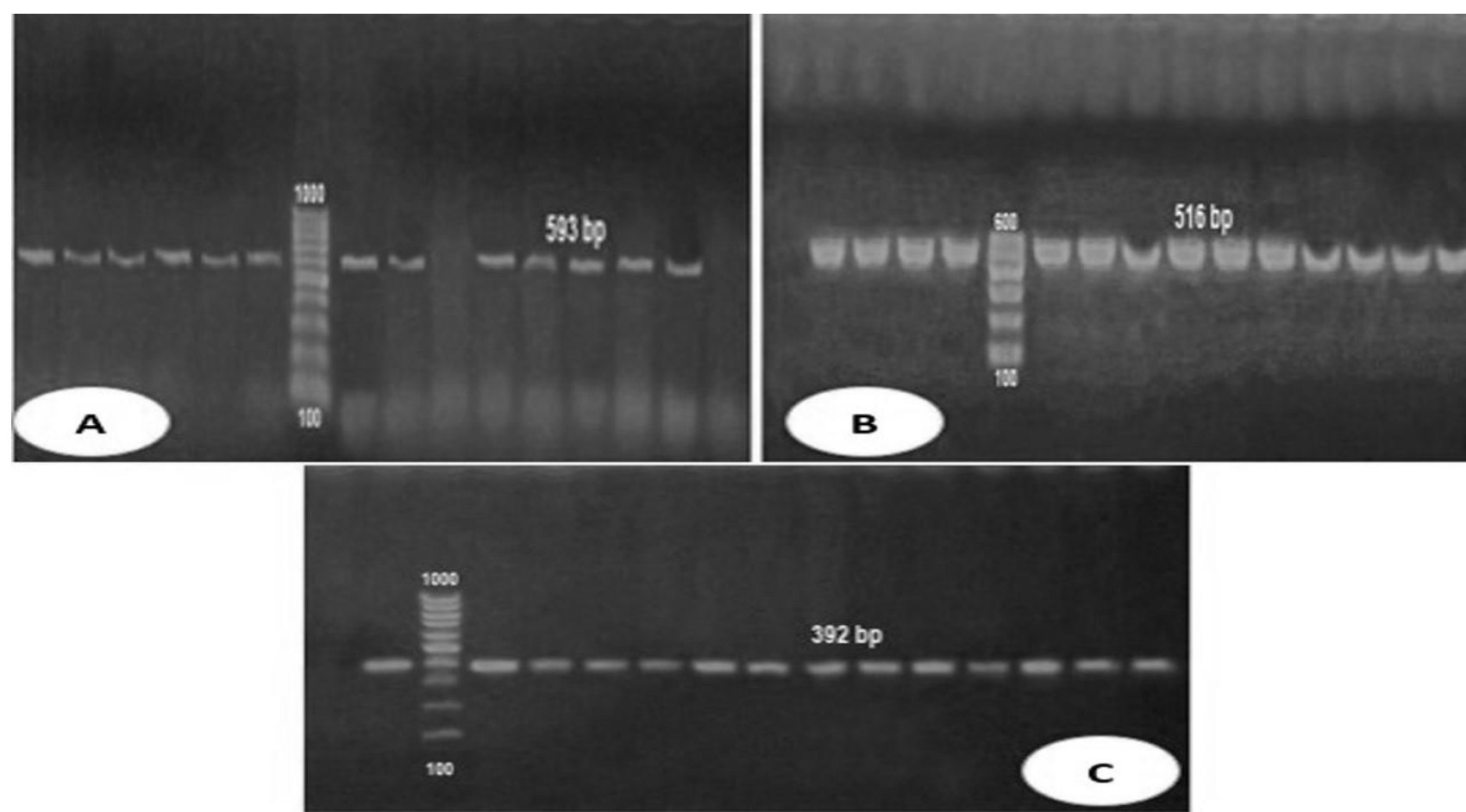

Figure 2. Agarose gel electrophoresis of A- blaCTX gene (Amplicon size593 bp), B- blaTEM gene (Amplicon size 516 bp), C-blaSHV gene ( Amplicon size 392 bp) Ladder [Gelpilot100 bp plus ladder (Qiagen, 100-1500 bp)]

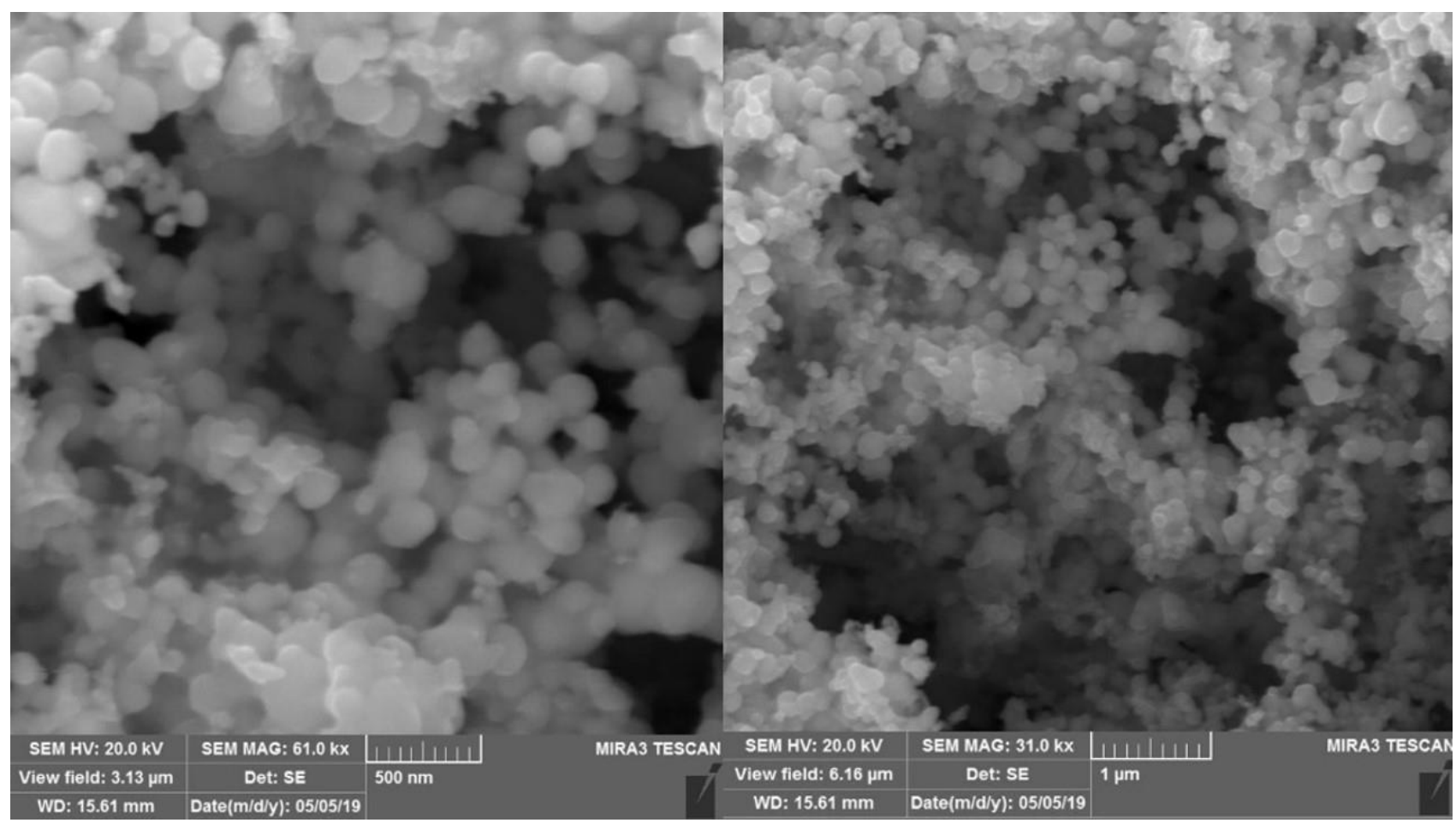

Figure 3. SEM of AgNPs revealed that Ag NPs are spherical in shape and the average size is $58 \mathrm{~nm}$. 

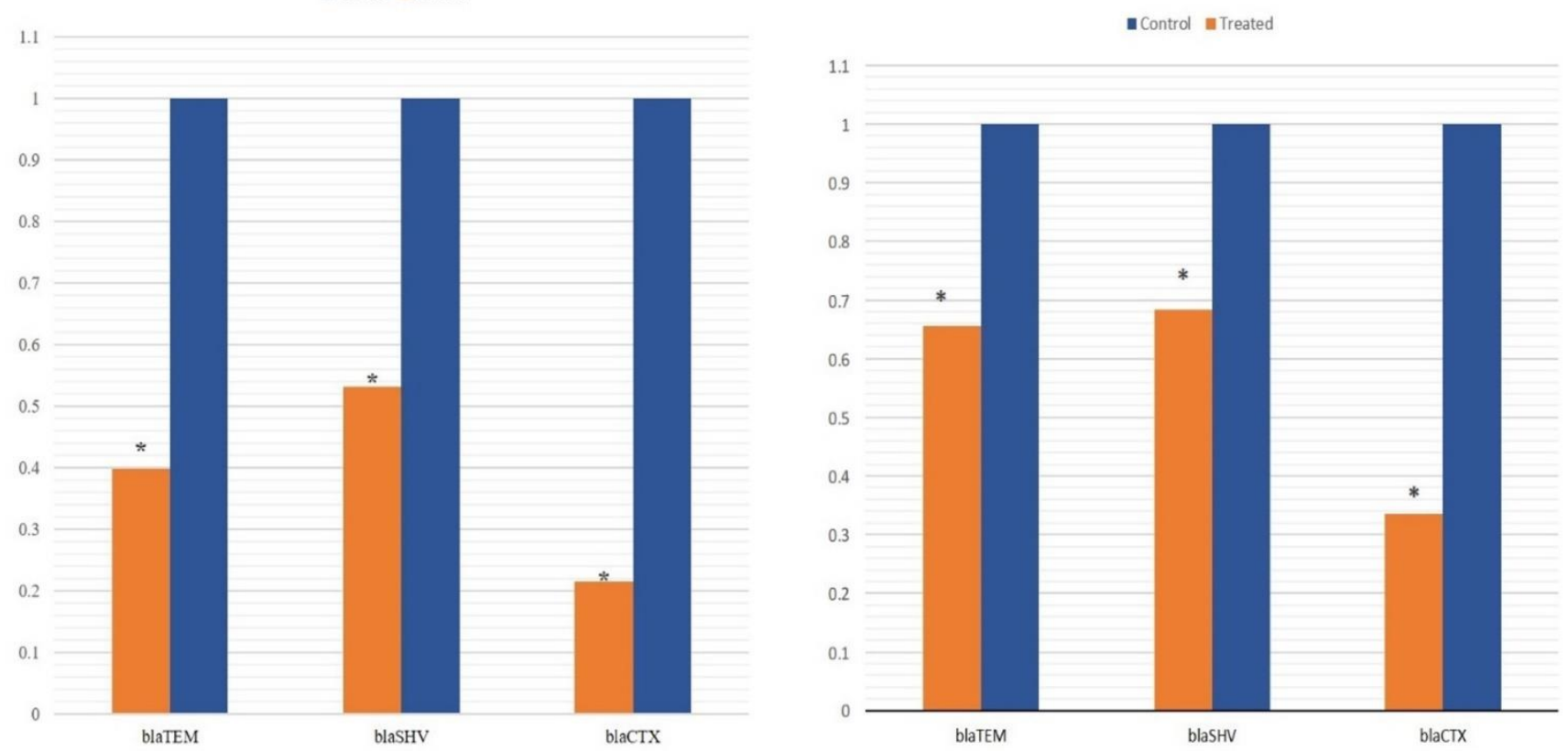

Figure 4. Effect of Silver nanoparticles on the antibiotic resistance genes expression in Left E. coli, Right Klebsiella spp. Stars indicate significant difference between control and treated samples for each gene.

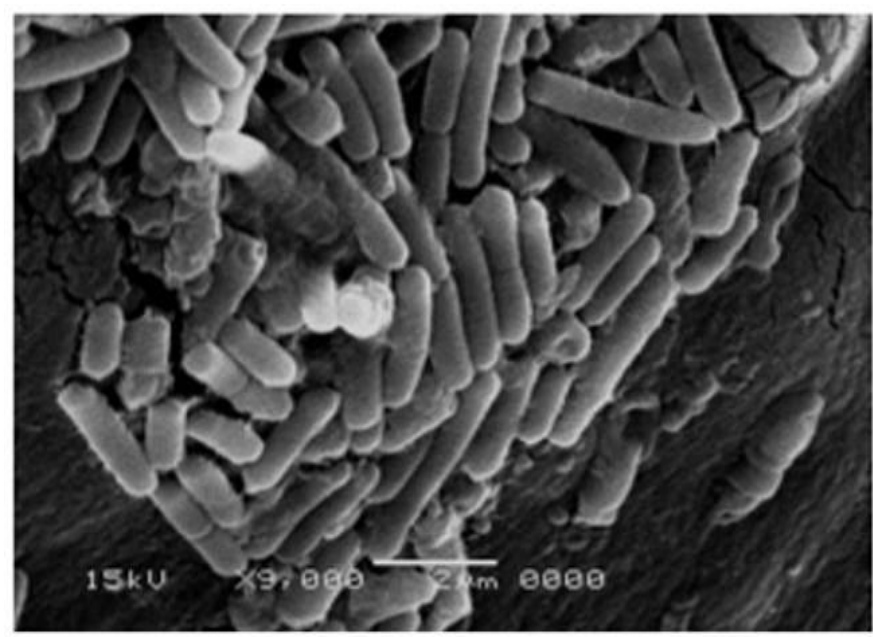

(a)

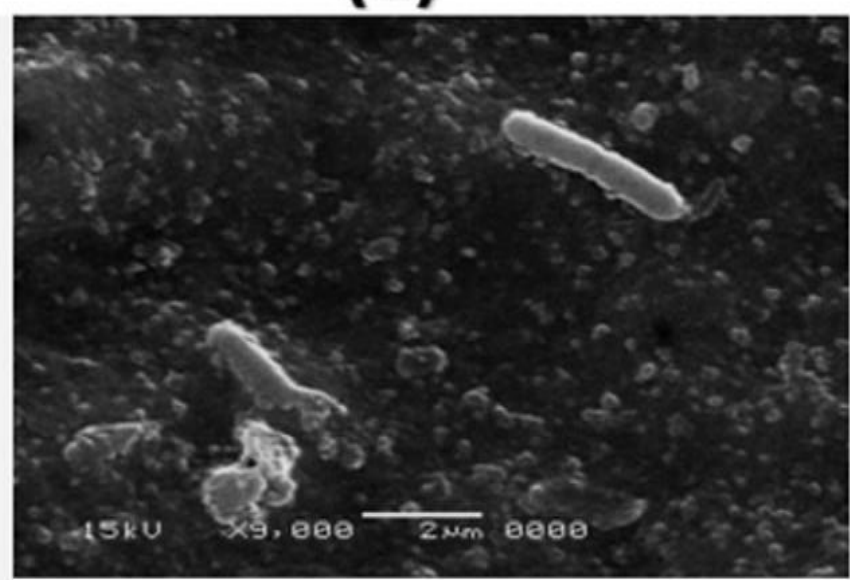

(c)

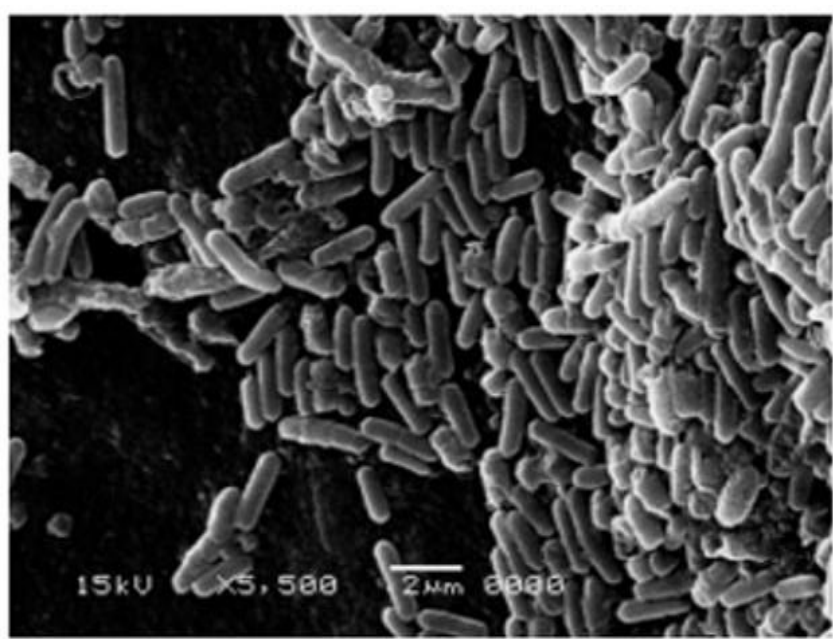

(b)

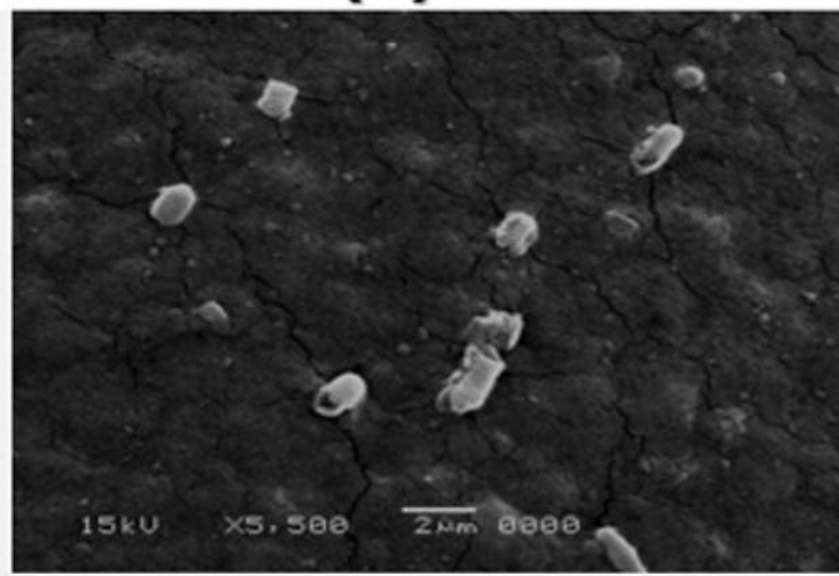

(d)

Figure 5. Scanning Election microscopic pictures of AgNPs treated and untreated E. Coli and Klebsiella spp. The control cells showed normal, clear and unpenetrated cell membrane (a, b). AgNps treated cells showed cell membrane penetration and perforation of cells leading to excretion of cell metabolites and cell death $(\mathbf{c}, \mathbf{d})$ 
Despite the presence of various modern antimicrobial agents and antibacterial drugs, bacterial infections are still a major threatening problem due to the enormous increase in multi-drug-resistant bacteria. Mobile genetic elements, such as plasmids, are capable of transferring antimicrobial resistance determinant elements among different bacterial populations and play an important role in the epidemiology of antimicrobial resistance (Carattoli, 2013). The extensive misuse of antibiotics has become a leading cause of the emergence of several hazards to public health, such as superbugs, which resist all the current drugs (Khameneh et al., 2016). The clinical effectiveness of beta-lactams has been diminished owing to the massive increase in resistant bacteria and prolonged patient recovery (Denisuik et al., 2013; Mathers et al., 2015). Extended-spectrum beta-lactamases (ESBLs) in pet animals is a threatening issue which has emerged worldwide. Since their emergence, ESBLs have most often been found in Escherichia coli and Klebsiella pneumonia (Bonnet 2004; Livermore et al. 2006; Mathers et al. 2015). In the present study, the prevalence of ESBL producing Escherichia coli and Klebsiella spp. was investigated in different samples obtained from pet animals. MacConkey agar (Oxoid) supplemented by Ampicillin was used for the isolation of ESBL-producing isolates which facilitate screening of the isolates rather than Macconkey supplemented with Cephalosporine as reported by Okapara et al. (2018). ESBL-producing E. coli and Klebsiella spp. were detected in 23 out of the 120 samples of the current study representing $19.6 \%$ of the total samples. In previous studies, ESBL- producing K.pneumoniae were recorded as 41\% (Okapara et al., 2018) and 7.5\% (Liu et al., 2017). ESBL-producing isolated E. coli was detected in 17 (14.16\%) samples, 7 from urine, and the other 10 from fecal samples. The obtained results of the current study were indicative of higher percentages, compared to those of ESBL isolated E. coli obtained from dogs and cats in Switzerland 8\% (Huber et al., 2013) and New Zealand 6.4\%, (Karkaba et al., 2019) and lower than those obtained from pet animals in Switzerland 54.7\%, (Zogg et al., 2018) and from dairy farms in Germany 75.6\%, (Odenthal et al., 2016). Three genes (i.e., TEM, SHV, and CTX-M) are the most predominant in ESBL-producing bacteria (Paterson and Bonomo, 2005). The blaSHV and blaTEM were detected in all the isolates while blaCTX-M was found in $92.3 \%$. Huber et al. (2013) investigated ESBL genes of ESBL producing $E$. coli isolates where blaCTX-M was found in $100 \%$ of isolates and blaTEM in $87.5 \%$. Searching new effective bactericidal alternatives has become an urgent issue for combatting drug resistance. Silver nanoparticles have been established as a promising approach as an alternative for antimicrobial agents in the treatment of several medicinal problems (Beyth et al., 2015; Hassanen and Ragab, 2020). They have attracted great concerted attention and have been broadly used in a variety of applications as antibacterial/antifungal agents in a diverse range of products, including air sanitizer sprays, pillows, respirators, wet wipes, detergents, soaps, shampoos, toothpaste, air filters, coatings of refrigerators, vacuum cleaners, washing machines, food storage containers, cellular phones (Sun et al., 2001). Moreover, they do not cause high level of toxicity in human as well as they have broad-spectrum antibacterial actions (Chandran et al., 2006).

In the present study, AgNPs were tested against ESBL-producing E. coli and Klebsiella spp. isolates in vitro by the detection of MIC and MBC. Manikprabhu and Lingappa (2014) determined the antibacterial effect of AgNPs with size (28-50nm) against ESBL producing E. coli where MIC and MBC were found to be (in the range of 0.11 and 0.22 $\mathrm{mg} / \mathrm{ml})$. Moreover, biogenic nanosilver of (20-70nm) was used against ESBL-producing $k$. pneumoniae and E. coli, where the recorded MIC and MBC were $1.4 \mu \mathrm{g}$ and $2 \mu \mathrm{g}$, respectively (Subashini et al., 2014). This indicated that AgNPS had a good bacteriostatic effect according to MIC and good bactericidal effect according to MBC on ESBL-producing $E$. coli and Klebsiella spp. As reported, the small size of nanoparticles potentiates the antibacterial effect on microorganisms (Smekalova et al., 2016). Also, AgNPs had the same effect against ESBL- and non ESBL- producing bacteria (Ansari et al., 2014).

It should be noted that it is not easy to compare the obtained results of the antibacterial effect of AgNPs in the current research with those of previous studies since different researchers employed different methods to study the antibacterial effect of AgNPs against different types of bacteria. Besides, the effect of AgNPs against microorganisms was influenced by the size, shape, stability, and concentration of AgNPs (Bandyopadhyay et al., 2018). We found that the concentration of AgNPs used to inhibit or kill microorganisms differed from one another as MIC and MBC values of AgNPs against E. coli were lower than those of Klebsiella spp.

In the current study, SYBR Green RT-PCR was used to investigate the influence of silver nanoparticles against ESBL-producing E. coli and Klebsiella spp. resistance genes (blaCTX-M, blaTEM, and blaSHV). The sub-MIC dose $(150 \mu \mathrm{g})$ of silver nanoparticles of average size $58 \mathrm{~nm}$ was tested against E. coli and showed the downregulation of blaCTX-M, blaTEM, and blaSHV genes with fold change about 0.21, 0.39, 0.53, respectively, for E. coli. Furthermore, the sub-MIC dose $(310 \mu \mathrm{g})$ of silver nanoparticles was tested against Klebsiella spp. and indicated the downregulation of genes expression with $0.33,0.65,0.68$ for blaCTX-M, blaTEM, and blaSHV resistance genes, respectively. These results indicated that AgNPs could effectively influence the gene expression of E. coli (blaCTX-M, blaTEM, and blaSHV) genes more than that of Klebsiella spp, which would subsequently reflect in their resistance pattern.

In the current study, the morphological changes in E. coli and Klebsiella spp. cells were evaluated before and after the treatment with silver nanoparticles using SEM. The SEM observations in treated cells confirmed cell membrane 
damage due to the adherence of AgNPs with bacterial cell membranes and penetration into the cells causing cell death. On the other hand, untreated cells indicated healthy cells with a clear unpenetrated cell membrane. The bactericidal effect of silver nanoparticles is still of unknown mechanism. Many studies suggest that their binding to the bacterial cell membrane may disrupt cell permeability (Kvítek et al., 2008) while other studies propose that the bactericidal effect did not only caused by contact with cell membrane but also because of penetration into the bacterial cell leading to the inactivation of DNA replication and causing cell death (Morones et al., 2005).

\section{CONCLUSION}

In the present study, the antibacterial effect of silver nanoparticles was investigated in vitro against Extended Spectrum Beta lactamase producing E. coli and Klebsiella spp. The findings revealed that using silver nanoparticles as an alternative to antimicrobial agents had an obvious effect on minimum inhibitory concentration, minimum bactericidal concentration, Bacterial cell wall integrity as well as genetically on the expression of antibiotic resistance genes. This trial is very encouraging for the control of antibiotic-resistant bacteria.

\section{DECLARATIONS}

\section{Authors' contributions}

Omnia A Khalil, Mona I Enbaawy, Eman Ragab, Hossam Mahmoud, and Taher Salah designed the plan of work, supervised the experiment, and revised the manuscript. Eman Ragab is the corresponding author and responsible for English editing, statistical analysis, and formatting the manuscript.

\section{Competing interests}

The authors declare no conflicts of interest.

\section{Consent to publish}

Written consent was obtained from the owners of the animals after they were informed on the use of their animal samples in the study

\section{REFERENCES}

Alyamani EJ, Khiyami AM, Booq RY, Majrashi MA, Bahwerth FS, and Rechkina E (2017). The occurrence of ESBL-producing Escherichia coli carrying aminoglycoside resistance genes in urinary tract infections in Saudi Arabia. Annals of Clinical Microbiology and Antimicrobials, 16(1): 1. DOI: https://www.doi.org/10.1186/s12941-016-0177-6

Ansari MA, Khan HM, Khan AA, Cameotra SS, Saquib Q, and Musarrat J (2014 ). Interaction of A 12 O 3 nanoparticles with E scherichia coli and their cell envelope biomolecules. Journal of applied microbiology, 116(4): 772-783. DOI: https://www.doi.org/10.1111/jam.12423

Archambault M, Petrov P, Hendriksen RS, Asseva G, Bangtrakulnonth A, Hasman H, and Aarestrup FM (2006). Molecular characterization and occurrence of extended-spectrum beta-lactamase resistance genes among Salmonella enterica serovar Corvallis Thailand, Bulgaria, and Denmark. Microbial Drug Resistance, 12(3): 192-198. DOI: https://www.doi.org/10.1089/mdr.2006.12.192

Bandyopadhyay S, Banerjee J, Bhattacharyya D, Samanta I, Mahanti A, Dutta TK, Ghosh S, Nanda PK, Dandapat P and Bandyopadhyay S (2018). Genomic identity of fluoroquinolone-resistant bla CTX-M-15-Type ESBL and pMAmpC $\beta$-lactamase producing Klebsiella pneumoniae from buffalo milk, India. Microbial Drug Resistance, 1: 24(9): 1345-1353. DOI: https://doi.org/10.1089/mdr.2017.0368

Beyth N, Houri-Haddad Y, Domb A, Khan W, and Hazan R (2015). Alternative antimicrobial approach: nano-antimicrobial materials. Evidence-Based Complementary and Alternative Medicine, 2015: 246012. DOI: http://dx.doi.org/10.1155/2015/246012

Bindu D, Mythili S, Inthira KS, palanisamy R, Lingesh KT, and Thandapani S (2015). New Generation of Silver Nanoparticles against Extended Spectrum Beta Lactamase Producing Organisms. International Journal of Drug Development \& Research, 7(3): 001-003. Available at: https://www.ijddr.in/drug-development/new-generation-of-silver-nanoparticles-against-extended-spectrum-betalactamase-producingorganisms.pdf

Brisse S, and Verhoef J (2001). Phylogenetic diversity of Klebsiella pneumonia and Klebsiella oxytoca clinical isolates revealed by randomly amplified polymorphic DNA, gyrA and parC gene sequencing and automated ribotyping. International Journal of Systematic and Evolutionary Microbiology, 51: 915-924. DOI:: https://www.doi.org/10.1099/00207713-51-3-915

Carattoli A. Plasmids and the spread of resistance( 2013) . International Journal of Medical Microbiology 1;303(6-7):298-304. DOI : https://doi.org/10.1016/j.ijmm.2013.02.001

Chandran SP, Chaudhary M, Pasricha R, Ahmad A, and Sastry M (2006). Synthesis of gold nanotriangles and silver nanoparticles using Aloe vera plant extract. Biotechnology Progress, 22: 577-583. DOI: https://www.doi.org/10.1021/bp0501423

Clinical and Laboratory Standards Institute (CLSI) (2018). Performance standards for antimicrobial susceptibility testing. 27th Informational Supplement Document M100- S27, CLSI, Wayne, 37(1). Available at :https://clsi.org/media/1469/m100s27_sample.pdf

Colom K, PèrezJ, Alonso R, Fernández-Aranguiz A, Lariňo E, and Cisterna R (2003). Simple and reliable multiplex PCR assay for detection of blaTEM,blaSHV and blaOXA-1 genes in Enterobacteriaceae. FEMS Microbiology Letters, 223: 147-151. DOI:https://www.doi.org/10.1016/S0378-1097(03)00306-9

Cruickshank R, Duguid RP, Marmion BP, and Swain RH (1975). Medical Microbiology.New York: Churchill Livingstone, Available at: https://agris.fao.org/agris-search/search.do?recordID=XF2015010062

Denisuik AJ, Lagacé-Wiens PR, Pitout JD, Mulvey MR, Simner PJ, Tailor F, Karlowsky JA, Hoban DJ, Adam HJ, and Zhanel GG ( 2013 ), Canadian Antimicrobial Resistance Alliance (CARA). Molecular epidemiology of extended-spectrum $\beta$-lactamase-, AmpC $\beta$-lactamase-and 
carbapenemase-producing Escherichia coli and Klebsiella pneumoniae isolated from Canadian hospitals over a 5 year period: CANWARD 200711. Journal of Antimicrobial Chemotherapy, 1: 68(suppl_1): 57-65. DOI: https://doi.org/10.1093/jac/dkt027

Devrim I, Gulfidan G, Gunay I, Agin H, Güven B, Yilmazer MM, and Dizdarer C (2011). Comparison of in vitro activity of ertapenemwith other carbapenems against extended- spectrum beta-lactamase-producing Escherichia coli and Kleibsella species isolated in a tertiary children's hospital. Expert Opinion on Pharmacotherapy, 12: 845-849. DOI: https://www.doi.org/10.1517/14656566.2011.559460

Ejaz H, Zafa A, Mahmood S, and Javed MM (2011). Urinary tract infections caused by extended spectrum $\beta$-lactamase (ESBL) producing Escherichia coli and Klebsiella pneumoniae. African Journal of Biotechnology, 10(73): 16661-16666. DOI https://www.doi.org/10.5897/AJB11.2449

Fan NC, Chen HH, Chen CL Ou LS, Lin TY, Tsai MH and Chiu CH (2014). Rise of community-onset urinary tract infection caused by extendedspectrum $\beta$-lactamase-producing Escherichia coli in children. Journal of microbiology,Immunology and Infection 47(5): 399-405. DOI: https://www.doi.org/10.1016/j.jmii.2013.05.006

Hamida RS, Ali MA, Goda DA, Khalil MI, and Redhwan A (2020). Cytotoxic effect of green silver nanoparticles against ampicillin resistant Klebsiella pneumoniae. Royal Socitey of Chemistry Advances, 10: 21136-21146. DOI: https://www.doi.org/10.1039/D0RA03580G

Hasman H, Mevius D, Veldman K, Olesen I and Aarestrup FM ( 2005). $\beta$-Lactamases among extended-spectrum $\beta$-lactamase (ESBL)-resistant Salmonella from poultry, poultry products and human patients in The Netherlands. Journal of Antimicrobial Chemotherapy. 1;56(1):115-21. Doi: https://doi.org/10.1093/jac/dki190

Hassanen EI, and Ragab E (2020). In Vivo and In Vitro Assessments of the Antibacterial Potential of Chitosan-Silver Nanocomposite Against Methicillin-Resistant Staphylococcus aureus-Induced Infection in Rats. Biological Trace Element Research, Apr 18: 1-4. DOI: https: www.doi.org/10.1007/s12011-020-02143-6

Huber H, Zweifel C, Wittenbrink MM, and Stephan R (2013). ESBL-producing uropathogenic Escherichia coli isolated from dogs and cats in Switzerland.Veterinary Microbiology, 162: 992-996. DOI: https://www.doi.org/10.1016/j.vetmic.2012.10.029.

Iqbal R, Ikram N, Shoaib M, Asad MJ, Tahir R, Mehmood, Niazi A, Asghar A, Bushra Ishfaq and Faiza Naseer (2017). Phenotypic cofirmatory disc diffusion test (PCDDT), double disc synergy test (DDST), E-test OS diagnostic tool for detection of extended spectrum beta lactamase (ESBL) producing Uropathogens. Journal of Applied Biotechnology and Bioengineering, 3(3): 344-349 DOI: https://www. doi.org/10.15406/jabb.2017.03.00068

Karkaba A, Hillb K, Benschop J, Pleydellc E, and Grinberg A (2019). Carriage and population genetics of extended spectrum $\beta$-lactamaseproducing Escherichia coli in cats and dogs in New Zealand.Veterinary Microbiology, 233: 61-67. DOI: https://www.doi.org/10.1016/j.vetmic.2019.04.015.

Keshari AK, Srivastava R, Singh P, Yadav B, and Nath G ( 2020). Antioxidant and antibacterial activity of silver nanoparticles synthesized by Cestrum nocturnum. Journal of Ayurveda and Integrative Medicine, 11(1): 37-44. DOI: https://www.doi.org/10.1016/j.jaim.2017.11.003

Khameneh B, Diab R, Ghazvini K, and Fazly Bazzaz BS (2016). Breakthroughs in bacterial resistance mechanisms and the potential ways to combat them. Microbial Pathogenesis, 95: 32-42. DOI: https://www.doi.org/10.1016/j.micpath.2016.02.009

Khan T, Yasmin A, and Townley HE (2020). An evaluation of the activity of biologically synthesized silver nanoparticles against bacteria, fungi and mammalian cell lines. Colloids and surfaces B: Biointerfaces, 194: 111156. DOI: https://www.doi.org/10.1016/j.colsurfb.2020.111156

Kizilca O, Siraneci R, and Yilmaz A (2012). Risk factors for community-acquired urinary tract infection caused by ESBL-producing bacteria in children. Pediatrics International, 54(6): 858-862. DOI: https://www.doi.org/10.1111/j.1442-200X.2012.03709.x

Kvítek L, Panáček A, Soukupova J, Kolář M, Večeřová R, Prucek R, Holecova M, and Zbořil R (2008). Effect of surfactants and polymers on stability and antibacterial activity of silver nanoparticles (NPs). The Journal of Physical Chemistry C, 17: 112(15): 5825-5834. DOI: https://www.doi.org/10.1021/jp711616v

Li WR, Xie XB, Shi QS, Zeng HY, OU-Yang YS, and Chen Y (2010). Antibacterial activity and mechanism of silver nanoparticles on Escherichia coli. Applied Microbiology and Biotechnology, 85: 1115-1122. DOI 10.1007/s00253-009-2159-5

Liu Y, Yang Y, Chen Y, and Xia Z (2017). Antimicrobial resistance profiles and genotypes of extended-spectrum b-lactamase- and AmpC blactamase-producing Klebsiella pneumoniae isolated from dogs in Beijing, China. Journal of Global Antimicrobial Resistance, 10: 219-222. DOI: https://www.doi.org/10.1016/j.jgar.2017.06.006

Livermore DM, Hope R, Fagan EJ, Warner M, Woodford N, and Potz N (2006 ). Activity of temocillin against prevalent ESBL-and AmpC-producing Enterobacteriaceae from south-east England. Journal of Antimicrobial Chemotherapy. 1:57(5):1012-4. DOI : https://doi.org/10.1093/jac/dk1043

Manikprabhu D, and Lingappa K (2014). Synthesis of silver nanoparticles using the Streptomycces Coelicolor Klmp33 pigment: An antibacterial agent against extended-spectrum beta-lactamase (ESBL) producing Escherichia Coli. Materials Science and Engineering C, 45: 434-437. DOI: https://www.doi.org/10.1016/j.msec.2014.09.034

Mathers AJ, Peirano G, and Pitout JD (2015). The role of epidemic resistance plasmids and international high-risk clones in the spread of multidrugresistant Enterobacteriaceae. Clinical microbiology reviews. 28(3):565-591. DOI: https://www.doi.org/10.1128/CMR.00116-14

Morones JR, Elechiguerra JL, Camacho A, Holt K, Kouri JB, Ramírez JT, and Yacaman MJ (2005). The bactericidal effect of silver nanoparticles. Nanotechnology, Aug 26; 16(10): 2346. DOI: https://www.doi.org/10.1088/0957-4484/16/10/059

Odenthal S, Akineden Ö and Usleber E (2016). Extended-spectrum $\beta$-lactamase producing Enterobacteriaceae in bulk tank milk from German dairy farms. International Journal of Food Microbiology, 238: 72-78. DOI: https://www.doi.org/10.1016/j.ijfoodmicro.2016.08.036

Okapara EO, Ojo EO, Awoyomi OJ, Dipeolu MA, Oyekunle MA, and Schwarz S ( 2018). Antimicrobial usage and presence of extended-spectrum- $\beta$ lactamase-producing Enterobactereaceae in animal-rearing households of selected rural and peri-urban communities.Veterinary Microbiology, 218: 31-39. DOI: https://www.doi.org/10.1016/j.vetmic.2018.03.013

Paterson DL and Bonomo RA (2005). Extended_spectrumbeta_lactamases: a clinical update. Clinical Microbiology Review,18: 657-686. DOI: https://www.doi.org/10.1128/CMR.18.4.657-686.2005

Saeb ATM, Alshammari AS, Al-Brahim H, and Al-Rubeaan KA ( 2014). Production of silver nanoparticles with strong and stable antimicrobial activity against highly pathogenic and multidrug resistant bacteria. Scientific World Journal, 1: $704-708$. DOI: https://www.doi.org/10.1155/2014/704708

Sambrook J, Fritsch EF, Maniatis T, and Sambrook-Fritsch-Maniatis (1989). Molecular Cloning: A Laboratory Manual ;[prepared for Use in the CSH Courses on the Molecular Cloning of Eukaryotic Genes]. Cold Spring Harbor Laboratory Press, Available at: https://www.cshlpress.com/pdf/sample/2013/MC4/MC4FM.pdf

Shahid M, Al-Mahmeed A, Murtadha MM, Qareeballa A, Eltahir MA, Tabbara KS, Ismaeel AY, Dar FK, Giha HA and Bindayna KM (2014). Characterization of cephalosporin-resistant clinical Enterobacteriaceae for CTX-M ESBLs in Bahrain. Asian Pacific Journal of Tropical Medicine, 7(1): S212-S216. DOI:https://www.doi.org/10.1016/s1995-7645(14)60234-0

Smekalova M, Aragon V, Panacek A, Prucek R, Zboril R and Kvitek L (2016). Enhanced antibacterial effect of antibiotics in combination with silver nanoparticles against animal pathogens. The Veterinary Journal, 209: 174-179. DOI: https://www.doi.org/10.1016/j.tvj1.2015.10.032 
Subashini J, Khanna VG, and Kannabiran K (2014). Anti-ESBL activity of silver nanoparticles biosynthesized using soil Streptomyces species Bioprocess and Biosystems Engineering, 37: 999-1006. DOI: https://www.doi.org/10.1007/s00449-013-1070-8

Sukmawinata E, Uemura R, Sato W, Thu Htun M, and Sueyoshi M ( 2020) . Multidrug-Resistant ESBL/AmpC-Producing Klebsiella pneumoniae Isolated from Healthy Thoroughbred Racehorses in Japan. Animals 10(3):369. DOI: https://doi.org/10.3390/ani10030369

Sun YP, Atorngitjawat P, and Meziani MJ (2001). Preparation of silver nanoparticles via rapid expansion of water in carbon dioxide micro-emulsiuon into reductant solution. Langmuir 17: 5707-5710. DOI: https:// www.doi.org/10.1021/la0103057

Tayel AA, El-Tras WF, Moussa S, El-Baz AF, Mahrous H, Salem MF, and Brimer L (2010). Antibacterial action of zinc oxide nanoparticles against foodborne pathogens. Journal of Food Safety, 31: 211-218. DOI: https://www.doi.org/10.1111/j.1745-4565.2010.00287.x

Thungrat K, price SB, Carpeter DM, and Boothe DM (2015). Antimicrobial susceptibility patterns of clinical Escherichia coli isolates from dogs and cats in the united states:january 2008 through january 2013.Veterinary Microbiology. 179(3-4) 287-295. DOI: https://www.doi.org/10.1016/j.vetmic.2015.06.012.

Tivendale KA, Allen JL,Ginns CA, Crabb BS, and Browning GF (2004). Association of iss and iucA, but not tsh, with plasmid- mediated virulence of avian pathogenic Escherichia coli. Infection and Immunity, 72(11): 6554-6560. DOI: https://www.doi.org/10.1128/IAI.72.11.6554-6560.2004

Wang Y, Hu Y, Cao J, Bi Y, Lv N, Liu F, Liang S, Shi Y,Jiao X, Gao GF, et al. (2019). Antibiotic resistance gene reservoir in live poultry markets. Journal of infection 78(6): 11-53. DOI: https://www.doi.org/10.1016/j.jinf.2019.03.012

Yuan JS, Reed A,Chen F, and Stewart CN (2006). Statistical analysis of real-time PCR data. BMC Bioinformatics, 7-85. Available at: https://bmcbioinformatics.biomedcentral.com/articles/10.1186/1471-2105-7-

Zogg AL, Zurfluha K, Schmittb S, Nüesch-Inderbinena M, and Stephana R (2018). Antimicrobial resistance, multilocus sequence types and virulence profiles of ESBL producing and non-ESBL producing uropathogenic Escherichia coli isolated from cats and dogs in Switzerland.Veterinary Microbiology, 216: 79-84. DOI: https://www.doi.org/10.1016/j.vetmic.2018.02.011. 